\title{
Content of toxic and essential metals in recrystallized and washed table salt in Shiraz, Iran
}

\author{
Mohammad Hassan Eftekhari ${ }^{1}$, Seyed Mohammad Mazloomi ${ }^{2}$, Marzieh Akbarzadeh ${ }^{1 *}$ and Mojdeh Ranjbar ${ }^{3}$
}

\begin{abstract}
Background: Table salt is the most commonly used food additive. Since most of the salt consumed in Iran comes from mines, contamination with heavy metals is a health concern. The commonest salt purification method in Iran is washing with water. But recently, some industries have turned to recrystallization method. The present study aimed to determine the level of essential and non-essential heavy metals in the table salt refined with recrystallization and washing methods.
\end{abstract}

Methods: Thirty eight pre-packed salt samples were directly collected from retail market in Shiraz (22 samples refined with recrystallization method and 16 with washing method). The level of lead, cadmium, copper, zinc, nickel and cobalt was determined using Voltammetric method. Daily intakes of lead and cadmium as well as their weekly intakes were calculated.

Results: The levels of lead, cadmium, copper, zinc, nickel and cobalt in recrystallized samples were $0.30 \pm 0.26$, $0.02 \pm 0.02,0.11 \pm 0.06,0.34 \pm 0.22,0.15 \pm 0.19$ and $0.008 \pm 0.007 \mu \mathrm{g} / \mathrm{g}$, respectively, and also $0.37 \pm 0.27$, $0.017 \pm 0.021,0.19 \pm 0.18,0.37 \pm 0.20,0.13 \pm 0.23$ and $0.037 \pm 0.06 \mu \mathrm{g} / \mathrm{g}$ in washed salt samples. The calculated weekly intake of lead and cadmium was 0.216 and $0.014 \mu \mathrm{g} / \mathrm{kg}$, respectively for the recrystallized and 0.2653 and $0.0119 \mu \mathrm{g} / \mathrm{kg}$ for the washed salts.

Conclusion: All values for toxic metals were lower than the permitted maximum for human consumption as prescribed by Codex and Institute of Standards and Industrial Research of Iran. Only 0.8652-1.0612\% of lead and $0.17-0.2 \%$ of cadmium PTWls are received via salt consumption weekly.

Keywords: Heavy metal, Sodium chloride, Wash

\section{Introduction}

The polluted environment surrounding us exposes humans to different toxic substances leading to several complex disorders such as cancer, cardiovascular, respiratory and some chronic diseases [1]. The most common pollutants and also the most toxic ones are air pollutants and contaminants found in drinking water and foodstuff [1].

Human exposure to environmental chemicals occurs spontaneously through different sources [2]. For nonoccupationally exposed humans, water and food consumption is the major route of exposure to toxic elements accounting for more than $90 \%$ of exposure to these substances, compared to that from inhalation and

\footnotetext{
* Correspondence: marzieh_akbarzadeh@yahoo.com

'Department of Clinical Nutrition, School of Nutrition and Food Sciences, Research Center for Health Sciences, Shiraz University of Medical Sciences, Shiraz, Iran

Full list of author information is available at the end of the article
}

dermal contacts [3,4]. Chemical products and heavy metals are hazardous substances found in foodstuff [5].

Nowadays, food products' contamination with heavy metals is an inevitable problem. Air, soil and water pollution leads to presence of these harmful elements such as lead, cadmium, mercury and arsenic in foodstuff [2]. Heavy metals are toxic to living organisms because they tend to accumulate in special tissues and contribute to several disorders [2].

Some elements such as lead, cadmium, mercury and arsenic are non-essential and are toxic even at low concentrations. Others such as copper and zinc are essential for humans; they play important roles in biological systems. When their intake exceeds special levels, they make harmful and toxic effects [6-9]. These non-essential heavy metals are toxic to cardiovascular, neural, hematopoietic, immunological and gastrointestinal systems [10-13]. They can also

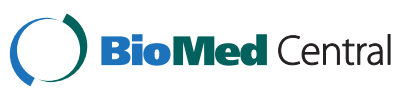


cause kidney dysfunction, anemia, liver toxicity, cancer and Alzheimer disease [10,12-15]. Because of chemical similarities, these heavy metals compete with essential elements and interact with several divalent transporters leading to disruption in different physiologic functions [10].

Table salt is one of the most commonly used food additives. In addition to salty flavor, it is used as flavor enhancer and also as a food preservative to inhibit the growth of spoilage and pathologic bacteria [9]. Since most of the salt consumed in the globe comes from mines, it is expected that heavy metal contamination is a serious concern about table salt [9]. Table salt is consumed daily, so any contamination, even at low levels, could be hazardous to the consumer's health. Therefore, the concentration of heavy metals should be carefully monitored in this food additive.

Most of the salt consumed in Iran comes from mines, but a small proportion comes from solar evaporation of saline sea water [16]. Usually two purification procedures are used to remove impurities from rock salt. One of these procedures is washing with water [17]; the other is recrystallization [18], and recently Salex method has been used [19]. The most commonly used system in salt refining in Iran is washing with water [20,21]. But nowadays, the number of salt brands refined with recrystallization method is increasing in the market. In recrystallization process, a brine solution is treated with chemicals that precipitate most impurities (largely magnesium and calcium salts). Multiple stage evaporation is then used to collect pure sodium chloride crystals [22].

Since there are limited data on the level of heavy metals in recrystallized and washed table salts, the present study aimed to determine the level of essential and non-essential heavy metals in the table salt refined with recrystallization and washing methods.

\section{Materials and methods}

Thirty eight pre-packed salt samples were directly collected from retail market in Shiraz (22 samples refined with recrystallization method and 16 with washing method). The level of lead, cadmium, copper, zinc, nickel and cobalt was determined using voltammetric method.

For the voltammetric measurement, a Polarograph/ Voltammetr instrumental Model 797 VA Computrace (Metrohm, Swiss) was used interfaced with a hanging mercury dropping electrode (HDME). Stripping was performed with a Teflon coated bar at about $400 \mathrm{rpm}$ using a magnetic stirrer (KIKA Labortechinik, Germany), Ag/ $\mathrm{AgCl}$ (in saturated $\mathrm{KCl}$ ) reference electrode, and auxiliary electrode of a platinum wire. At the beginning of the experiment, the solutions were deoxygenated with high purity nitrogen for $5 \mathrm{~min}$, whereas before each analysis the solution was deoxygenated for $2 \mathrm{~min}$.

\section{Voltammetric measurement}

Five grams of the sample salt was first dissolved in $50 \mathrm{ml}$ water. Then, $10 \mathrm{ml}$ of the sample was transferred into the voltammetric cell containing $1 \mathrm{ml}$ of acetate buffer $(\mathrm{pH}=4.6)$. The solution in the cell was aerated for $5 \mathrm{mi}-$ nutes by purging pure nitrogen gas. Anodic stripping was performed in differential pulse mode after selecting pre-concentration time of $180 \mathrm{~s}$, a scan rate of $4 \mathrm{mV} / \mathrm{s}$ and pulse amplitude of $50 \mathrm{mV}$. The concentrations of all the metals in the samples were determined using standards addition method on the Hanging Mercury Dropping Electrode (HDME) by means of Anodic Stripping Voltammetry (ASV).

The dietary intake of the studied heavy metals was also estimated and their associated risks were studied by comparing to the provisional tolerable weekly intakes (PTWIs). Considering the average daily salt intake to be 6 g/day [23-25], PTWI was calculated as follows:

$$
\begin{aligned}
& \text { Daily intake of heavy metals } \\
& =\text { concentration of heavy metals in the salts } \\
& \quad \times \text { mean salt intake }(\mathrm{g} / \text { person } / \text { day })
\end{aligned}
$$

Weekly intake of heavy metals

$$
=\text { daily intake } \times \text { seven days/week }
$$

$$
\begin{aligned}
& \text { Weekly intake per body weight }(\mathrm{kg}) \text { (PTWIs) } \\
& =\text { weekly intake } \div \text { reference body weight }(60 \mathrm{~kg})
\end{aligned}
$$

\section{$[23,26]$}

The percentage of PTWI via salt consumption was also calculated.

\section{Statistical analysis}

Data processing and analysis were done using SPSS, version 17 for windows (SPSS Inc, Chicago, USA). All data were expressed as mean $( \pm$ Standard Deviation). We compared the metal contents of recrystallized and washed salts using Mann-Whitney $U$ test. Significance level was set at $\mathrm{p}<0.05$.

\section{Results and discussion}

Samples of salt refined with recrystallization and washing method were analyzed for lead, cadmium, copper, zinc, nickel and cobalt content. Comparison of heavy metal concentrations between table salt samples refined by recrystallization and washing methods is presented in Table 1. The values are reported based on dry weight. There were no significant differences between the two salt groups in lead, cadmium, copper, zinc and nickel 
Table 1 Comparison of heavy metal concentrations between table salt samples refined by recrystallization and washing methods*

\begin{tabular}{|c|c|c|c|c|c|c|c|}
\hline & \multicolumn{2}{|c|}{ Recrystallized salts } & \multicolumn{2}{|c|}{ Washed salts } & \multirow[t]{2}{*}{ P-value } & \multirow{2}{*}{$\begin{array}{l}\text { Iranian food } \\
\text { standard limits }\end{array}$} & \multirow{2}{*}{$\begin{array}{l}\text { Codex standarc } \\
\text { limits }\end{array}$} \\
\hline & Mean \pm SD & Range & Mean \pm SD & Range & & & \\
\hline Lead $(\mu \mathrm{g} / \mathrm{g})$ & $0.309 \pm 0.263$ & $0.021-0.921$ & $0.379 \pm 0.276$ & $0.096-0.929$ & 0.234 & 1.0 & 2.0 \\
\hline Cadmium ( $\mu \mathrm{g} / \mathrm{g})$ & $0.020 \pm 0.020$ & $0.0026-0.078$ & $0.017 \pm 0.021$ & $0.005-0.093$ & 0.765 & 0.2 & 0.5 \\
\hline Copper $(\mu \mathrm{g} / \mathrm{g})$ & $0.114 \pm 0.064$ & $0.026-0.234$ & $0.198 \pm 0.180$ & $0.040-0.634$ & 0.152 & 2.0 & 2.0 \\
\hline $\operatorname{Zinc}(\mu \mathrm{g} / \mathrm{g})$ & $0.341 \pm 0.228$ & $0.049-0.829$ & $0.376 \pm 0.202$ & $0.120-0.663$ & 0.404 & - & - \\
\hline Nickel $(\mu \mathrm{g} / \mathrm{g})$ & $0.152 \pm 0.194$ & $0.013-0.76$ & $0.139 \pm 0.233$ & $0.009-0.920$ & 0.284 & - & - \\
\hline Cobalt $(\mu \mathrm{g} / \mathrm{g})$ & $0.008 \pm 0.007$ & $0.0002-0.026$ & $0.037 \pm 0.069$ & $0.001-0.290$ & 0.020 & - & - \\
\hline
\end{tabular}

*Mann-Whitney U test.

content. Only the cobalt concentration was significantly higher in washed compared to the recrystallizad salts.

Lead is a heavy metal that accumulates in the body and affects different systems and organs such as central and peripheral neural system, gastrointestinal tract, muscles, kidneys and hematopoietic system [27]. The maximum permitted level of lead in food grade salt is $2.0 \mu \mathrm{g} / \mathrm{g}$ according to the Codex legislation [28] and $1.0 \mu \mathrm{g} / \mathrm{g}$ according to the Iranian food standards [29]. In our recrystallized and washed salt samples, lead content was $0.30 \mu \mathrm{g} / \mathrm{g}$ and $0.37 \mu \mathrm{g} / \mathrm{g}$ respectively, which is below the permitted levels. In another report in Iran, lead concentration was $2.728 \mu \mathrm{g} / \mathrm{g}$ (range 0.01-5.8 $\mu \mathrm{g} / \mathrm{g}$ ) [9] and in salt samples from Tehran, lead content was $0.87 \mu \mathrm{g} / \mathrm{g}$ [16] and $0.438 \mu \mathrm{g} / \mathrm{g}$ [22]. In a study in Isfahan, lead content was determined to be $0.57 \mu \mathrm{g} / \mathrm{g}$ [23]. In the literature, it was reported in the range of $0.5-1.64 \mu \mathrm{g} / \mathrm{g}$ in refined and unrefined table salt samples from Turkey, Egypt and Greece [30] and $0.03 \mu \mathrm{g} / \mathrm{g}$ in Brazil [31].

Cadmium exposure induces bone damage, osteoporosis, and renal tubular dysfunction that leads to renal failure in long term $[27,32,33]$. It is also associated with several cancers [34-36]. In our recrystallized and washed samples, cadmium content was $0.02 \mu \mathrm{g} / \mathrm{g}$ and $0.017 \mu \mathrm{g} / \mathrm{g}$, respectively. In other reports of Iran, cadmium content was $0.01-0.4 \mu \mathrm{g} / \mathrm{g}$ [9], $0.65 \mu \mathrm{g} / \mathrm{g}$ [16] and 0.024 [22] in salt samples from Tehran, and $0.15 \mu \mathrm{g} / \mathrm{g}$ [23] in Isfahan. In Brazil, cadmium content of salts was $0.01-0.03 \mu \mathrm{g} / \mathrm{g}$ [31], and in a study by Soylak et al., it was 0.014-0.030 $\mu \mathrm{g} / \mathrm{g}$ in refined and unrefined table salt samples from Turkey, Egypt and
Greece [30]. According to Codex legislation and Iranian food standards, the maximum permitted level of cadmium in food grade salt is 0.5 and $0.2 \mu \mathrm{g} / \mathrm{g}$, respectively [28,29]. The cadmium content of our samples was less than these figures.

Copper is essential for good health, but its high intake leads to liver and kidney damage [9]. Based on Codex legislation [28] and Iranian food standards [29], the maximum permitted level of copper in food grade salt is 2.0 $\mu \mathrm{g} / \mathrm{g}$. In our samples, copper was $0.11 \mu \mathrm{g} / \mathrm{g}$ in recrystallized ones and $0.19 \mu \mathrm{g} / \mathrm{g}$ in washed ones, which is below the permitted levels, and as predicted, higher in washed salts than recrystallized type. Copper content was reported to be $1.21 \mu \mathrm{g} / \mathrm{g}$ [16] in Tehran and $0.87 \mu \mathrm{g} / \mathrm{g}$ [23] in Isfahan salt samples. In another report in Iran, copper concentration was in the range of 0.1-2.8 $\mu \mathrm{g} / \mathrm{g}$ [9]. Copper content was 0.17-0.47 $\mu \mathrm{g} / \mathrm{g}$ in Soylak's study [30].

Similar to copper, zinc is an essential element at low concentrations, but in excessive levels, it has potential hazards to both animal and human health [37]. Zinc concentration was $0.34 \mu \mathrm{g} / \mathrm{g}$ in our recrystallized and $0.37 \mu \mathrm{g} / \mathrm{g}$ in washed salt samples. In Tehran and Isfahan salts, zinc content was reported to be $6.50 \mu \mathrm{g} / \mathrm{g}$ [16] and $6.34 \mu \mathrm{g} / \mathrm{g}$ [23].

Toxic effects of Nickel have been reported on the respiratory system, gastrointestinal tract, liver, and kidneys $[21,38]$. It also leads to neurological disorders [21,39]. In the only study in Iran, nickel content was reported to be $1.860 \mu \mathrm{g} / \mathrm{g}$ in refined table salt [21]. In our study, nickel concentration was $0.15 \mu \mathrm{g} / \mathrm{g}$ and $0.13 \mu \mathrm{g} / \mathrm{g}$ in

Table 2 Exposure to lead and cadmium through salt intake

\begin{tabular}{|c|c|c|c|c|c|c|}
\hline \multirow{2}{*}{$\begin{array}{l}\text { Heavy } \\
\text { metals }\end{array}$} & \multirow{2}{*}{$\begin{array}{c}\text { Salt } \\
\text { samples }\end{array}$} & \multirow{2}{*}{$\begin{array}{l}\text { Daily intake } \\
\text { ( } \mu \mathrm{g} / \text { person) }\end{array}$} & \multicolumn{2}{|c|}{ Weekly intake (WI) } & \multirow{2}{*}{$\begin{array}{c}\text { PTWI } \\
(\mu \mathrm{g} / \mathrm{kg} \mathrm{BW})\end{array}$} & \multirow{2}{*}{$\begin{array}{l}(\mathrm{WI} / \mathrm{PTWI}) \times 100 \\
(\% \text { intake via salt }\end{array}$} \\
\hline & & & ( $\mu \mathrm{g} /$ person) & $(\mu \mathrm{g} / \mathrm{kg} \mathrm{BW})$ & & \\
\hline \multirow[t]{2}{*}{ Lead } & Recrystallized & 1.854 & 12.978 & 0.216 & \multirow{2}{*}{$25^{*}$} & 0.8652 \\
\hline & Washed & 2.274 & 15.918 & 0.2653 & & 1.0612 \\
\hline \multirow[t]{2}{*}{ Cadmium } & Recrystallized & 0.12 & 0.84 & 0.014 & \multirow{2}{*}{$7^{* *}$} & 0.2 \\
\hline & Washed & 0.102 & 0.714 & 0.0119 & & 0.17 \\
\hline
\end{tabular}

*FAO/WHO, 1993 [41].

**Adapted from FAO/WHO, 2003 [42]. 
recrystallized and washed salt samples, respectively. Soylac et al. reported the nickel content of refined table salt samples from Turkey, Egypt and Greece to be 0.16$1.57 \mu \mathrm{g} / \mathrm{g}$ [30].

Increased Cobalt level in the body negatively affects the fetus growth. It also interacts with physiologic actions of divalent metals such as calcium, magnesium, and biologic functions of vitamin dependent coenzymes [21,40]. In another study, cobalt concentration was determined to be 3.7 $\mu \mathrm{g} / \mathrm{g}$ in refined table salts in Iran. In our recrystallized and washed samples, cobalt concentration was $0.008 \mu \mathrm{g} / \mathrm{g}$ and $0.037 \mu \mathrm{g} / \mathrm{g}$, respectively. Cobalt content was $0.22-0.48 \mu \mathrm{g} / \mathrm{g}$ in Soylak's study [30].

As we expected, lead, copper and zinc content was lower in recrystallized salts than the washed ones, but the difference was not statistically significant. Only cobalt content was significantly lower in recrystallized salts, compared to washed salts.

The calculated weekly intakes compared to their PTWIs are shown in Table 2. If people consume only recrystallized refined table salts, then we can say that their weekly intake of lead and cadmium is respectively 0.216 and $0.014 \mu \mathrm{g} / \mathrm{kg}$ body weight; If washed salt is used solely, then the weekly intake would be 0.2653 and $0.0119 \mu \mathrm{g} / \mathrm{kg}$ body weight for lead and cadmium, respectively, being far lower than the suggested PTWIs by the Joint FAO/WHO Expert committee on Food Additives (JECFA) [41]. By this consideration, people in Shiraz consume 0.8652-1.0612\% of lead and 0.17$0.2 \%$ of cadmium PTWIs via salt consumption.

\section{Conclusion}

All values for toxic metals were lower than the permitted maximum for human consumption as prescribed by Codex and ISIRI, and only $0.8652-1.0612 \%$ of lead and $0.17-0.2 \%$ of cadmium PTWIs are received via salt consumption weekly.

\section{Abbreviations}

PTWI: Provisional tolerable weekly intakes; HDME: Hanging mercury dropping electrode; ASV: Anodic stripping voltammetry.

\section{Competing interests}

The authors declare that they have no competing interests.

\section{Authors' contributions}

MHE helped in the design of the study and analytical phase. SMM participated in the design of the study, analytical phase, statistical analysis and drafted the manuscript. MA participated in the design of the study, analytical phase, statistical analysis and drafted the manuscript. MR helped in the analytical phase, and drafted the manuscript. All authors read and approved the final manuscript.

\section{Acknowledgement}

The present study was funded by the grant number 89-5220 from the Research Center for Health Sciences of Shiraz University of Medical Sciences. We gratefully acknowledge Sh. Simayeetabar for her assistance in the sample analysis.

\section{Author details}

'Department of Clinical Nutrition, School of Nutrition and Food Sciences, Research Center for Health Sciences, Shiraz University of Medical Sciences, Shiraz, Iran. ${ }^{2}$ Department of Food Hygiene and Quality Control, School of Nutrition and Food Sciences, Shiraz University of Medical Sciences, Shiraz, Iran. ${ }^{3}$ Department of Environmental Health Engineering, School of Health, Shiraz University of Medical Sciences, Shiraz, Iran.

Received: 1 July 2013 Accepted: 15 October 2013

Published: 7 January 2014

\section{References}

1. Scheen AJ, Giet D: Role of environment in complex diseases: air pollution and food contaminants. Rev Med Liege 2012, 67(5-6):226-233.

2. Zukowska J, Biziuk M: Methodological evaluation of method for dietary heavy metal intake. J Food Sci 2008, 00(0):R1-R9.

3. Chen C, Qian Y, Chen Q, Li C: Assessment of daily intake of toxic elements due to consumption of vegetables, fruits, meat, and seafood by inhabitants of Xiamen, China. J Food Sci 2011, 76(8):181-188.

4. Falco G, Llobet JM, Bocio A, Domingo JL: Daily intake of arsenic, cadmium, mercury, and lead by consumption of edible marine species. J Agric Food Chem 2006, 54:6106-6112.

5. Coduro E: Chemical contaminants in food. Zentralbl Bakteriol Mikrobiol Hyg B 1986, 183(2-3):221-233.

6. Celik U, Oehlenschlager J: High contents of cadmium, lead, zinc and copper in popular fishery products sold in Turkish supermarkets. Food Control 2007, 18(3):258-261.

7. Ikem A, Egiebor NO: Assessment of trace elements in canned fishes (Mackerel, Tuna, Salmon, Sardines and Herrings) marketed in Georgia and Alabama (United States of America). J Food Compos Anal 2005, 18:771-787.

8. Zarei M, Mollaie A, Eskandari MH, Pakfetrat S, Shekarforoush S: Histamine and heavy metals of canned tuna fish. Global Vet 2010, 5(5):259-263.

9. Zarei M, Eskandari MH, Pakfetrat S: Determination of heavy metals content of refined table salts. American-Eurasian Journal of Toxicological Sciences 2011, 3(2):59-62

10. Inbaraj $\mathrm{BS}$, Chen $\mathrm{BH}$ : In vitro removal of toxic heavy metals by poly( $\gamma$-glutamic acid)-coated superparamagnetic nanoparticles. Int $\mathrm{J}$ Nanomedicine 2012, 7:4419-4432. doi:10.2147/JN.S34396.

11. Tandon SK, Singh S: Role of vitamins in treatment of lead intoxication. $J$ Trace Elem Exp Med 2000, 13(3):305-315.

12. Barbier O, Jacquillet G, Tauc M, Cougnon M, Poujeol P: Effect of heavy metals on, and handling by, the kidney. Nephron Physiol 2005, 99(4):105-110.

13. Sabolić I: Common mechanisms in nephropathy induced by toxic metals. Nephron Physiol 2006, 104(3):107-114.

14. Damek-Poprawa M, Sawicka-Kapusta K: Histopathological changes in the liver, kidneys, and testes of bank voles environmentally exposed to heavy metal emissions from the steelworks and zinc smelter in Poland. Environ Res 2004, 96(1):72-78.

15. Neri LC, Hewitt D: Aluminum, Alzheimer's disease, and drinking water. Lancet 1991, 338(8763):390.

16. Jahed Khaniki GR, Dehghani MH, Mahvi AH, Nazmara S: Determination of trace metal contaminants in edible salts in Tehran (Iran) by atomic absorption spectrophotometry. J Biol Sci 2007, 7:811-814.

17. Anonymous Official Methods of Analysis: 14th Edition Association of Official nalytical Chemists. 1984, 33:14.

18. Mullin JW: Crystallization. 3rd edition. Oxford: Butterworth-Heinemann Ltd; 1993.

19. Sedivy VM: Purification of salt for chemical and human consumption. Zurich, Switzerland: KREBS SWISS; 1996

20. Elsagh A, Rabani M: Effect of water hardness on purity of $\mathrm{NaCl}$. Specialty Semiannual Journal of Salt 2010, 1:53-62.

21. Elsagh A: Determination of heavy metals $(\mathrm{Ni}, \mathrm{Cr}, \mathrm{Mn}, \mathrm{Co})$ in table salt refined with washing method and its comparison with unrefined rock salt. Iranian Food Science and Technilogy Research Journal 2012, 7(4):336-340.

22. Cheraghali A, Kobarfard F, Faeizy N: Heavy metals contamination of table salt consumed in Iran. Iranian Journal of Pharmaceutical Research 2010, 9(2):129-132. 
23. Pourgheysari $H$, Moazeni M, Ebrahimi A: Heavy metal content in edible salts in Isfahan and estimation of their daily intake via salt consumption. Int J Env Health Eng 2012, 1(1):41-45.

24. Mahan LK, Escott-Stump S: Krause's food and nutrition therapy. 11 thth edition. St. Louis: Elsevier Saunders, Philadelphia, USA; 2008:900-916.

25. Ireland DM, Clifton PM, Keogh JB: Achieving the salt intake target of $6 \mathrm{~g} /$ Day in the current food supply in free-living adults using two dietary education strategies. J Am Diet Assoc 2010, 110:763-767.

26. Lee HS, Cho YH, Park SO, Kye SH, Kim BH, Hahm TS, et al: Dietary exposure of the Korean population to arsenic, cadmium, lead and mercury. $J$ Food Compost Anal 2006, 19:S31-S37.

27. Ciobanu C, Slencu BG, Cuciureanu R: Estimation of dietary intake of cadmium and lead through food consumption. Rev Med Chir Soc Med Nat lasi 2012, 116(2):617-623.

28. Codex Alimentarius Commission: Codex standard for food grade salt. CX STAN 150-1985, Amend, 3-2006. 2006:1-7. URL: http://www.docstoc. $\mathrm{com} /$ ?docld $=155745518 \&$ download $=1$

29. ISIRI: Food grade salt specifications. No. 26, $3^{\text {rd }}$ revision. Institute of Standards and Industrial Research of Iran (ISIRI).

30. Soylak M, Peker DS, Turkoglu O: Heavy metal contents of refined and unrefined table salts from Turkey, Egypt and Greece. Environ Monit Assess 2008, 143(1-3):267-272.

31. Amorim FAC, Ferreira SLC: Determination of cadmium and lead in table salt by sequential multi-element flame atomic absorption spectrometry. Talanta 2005, 65:960-964.

32. Al-Rmalli SW, Jenkins $R O$, Haris P: Dietary intake of cadmium from Bangladeshi foods. J Food Sci 2012, 77(1):T2-T33. 10.1111/j.17503841.2011.02467.x. Epub 2011 Nov 28.

33. Engström A, Michaëlsson K, Vahter M, Julin B, Wolk A, Åkesson A: Associations between dietary cadmium exposure and bone mineral density and risk of osteoporosis and fractures among women. Bone 2012, 50:1372-1378.

34. Satarug S: Long-term exposure to cadmium in food and cigarette smoke, liver effects and hepatocellular carcinoma. Curr Drug Metab 2012, 13(3):257-271.

35. Julin B, Wolk A, Bergkvist L, Bottai M, Akesson A: Dietary cadmium exposure and risk of postmenopausal breast cancer: a population-based prospective cohort study. Cancer Res 2012, 72(6):1459-1466.

36. Sawada N, Iwasaki M, Inoue M, Takachi R, Sasazuki S, Yamaji T, Shimazu T, Endo $Y$, Tsugane S: Long-term dietary cadmium intake and cancer incidence. Epidemiology 2012, 23(3):368-376.

37. Papagiannis I, Kagalou I, Leonardos J, Petridis D, Kalfakakou V: Copper and zinc in four freshwater fish species from Lake Pamvotis (Greece). Enzviron Int 2004, 30:357-362.

38. Aktas YK, Ibar H: Determination of chromium, copper, manganese, nickel and zinc by flame atomic absorption spectrometry after separation of bentonite modified with trioctylamine. J Indian Chem Soc 2005, 82:134-136.

39. Zemanova J, Lukac N, Massanyi P, Trandzik J, Burocziova M, Nad P, et al: Nickel seminal concentrations in various animals and correlation to spermatozoa quality. J Vet Med A 2007, 54:281-286.

40. Saulea M, Stoica Al, Baiulescu GE, Marinescu D, lonica M: Determination of cobalt in food samples. Rev Chim 2004, 55:301-303.

41. Evaluation of certain food additives and contaminants. $41^{\text {st }}$ Report of Joint FAO/WHO Committee on Food Additives. Geneva, Switzerland; 1993.

42. Joint FAONHO expert committee on food additives. Sixty-first meeting. Rome; 2003.

doi:10.1186/2052-336X-12-10

Cite this article as: Eftekhari et al:: Content of toxic and essential metals

in recrystallized and washed table salt in Shiraz, Iran. Journal of

Environmental Health Sciences \& Engineering 2014 12:10.

\section{Submit your next manuscript to BioMed Central and take full advantage of:}

- Convenient online submission

- Thorough peer review

- No space constraints or color figure charges

- Immediate publication on acceptance

- Inclusion in PubMed, CAS, Scopus and Google Scholar

- Research which is freely available for redistribution
C Biomed Central 